\title{
Transcription of Complementary Repeat Sequences in Amphibian Oocytes *
}

\author{
John Sommerville ${ }^{1}$ and Ulrich Scheer ${ }^{2}$ \\ 1 Department of Zoology, University of St. Andrews, St. Andrews Fife KY16 9TS, Scotland; \\ 2 Division of Membrane Biology and Biochemistry, Institute of Cell and Tumor Biology, \\ German Cancer Research Center, D-6900 Heidelberg, Federal Republic of Germany
}

\begin{abstract}
Repeat sequences are transcribed in the germinal vesicles of amphibian oocytes. In the hnRNA population both complements of the repeats are found and can be readily detected because they form intermolecular duplex structures. The structure and formation of duplex regions have been studied in the hnRNA of Xenopus laevis, Triturus cristatus, Amphiuma means and Necturus maculosus, a series of amphibians of increasing genome size (C-value). In T. cristatus, the duplex structures are mostly $600-1200 \mathrm{bp}$ in length, whereas in $X$. laevis they are shorter and in $N$. maculosus they tend to be longer. Although the proportion of RNA sequence capable of rapidly forming duplex structures is different in different organisms, this property bears no relationship to $\mathrm{C}$-value. However the sequence complexity of complementary repeats, as estimated from the rate of duplex formation, does show an increasing trend with C-value. The complementary repeats found in oocyte hnRNA are transcribed from families of DNA sequence that are each represented in the genome by thousands of copies. The extent of cross-species hybridization is low, indicating that the repeat sequences transcribed in different amphibian genera are not the same. In situ hybridization experiments indicate that the repeat sequences are spread throughout the genome. The evolution and possible function of complementary repeats are considered.
\end{abstract}

\section{Introduction}

A commonly recognized feature of heterogeneous nuclear RNA (hnRNA) molecules is the presence of complementary repeat sequences which can form double-stranded regions either in vivo or after allowing isolated RNA molecules to anneal. Three types of secondary structure can be formed depending upon the location of the complementary repeats within the RNA molecules. Immediately adjacent repeats form hairpin structures, more dis-

* Dedicated to Professor H.G. Callan F.R.S. on the occasion of his retirement 
tally located repeats in the same molecule form stem-loop structures and repeats contained in different molecules form intermolecular hybrids. These various structures have been described for hnRNA molecules isolated from a variety of cell types (Ryskov et al., 1972; Jelinek et al., 1980; Fedoroff et al., 1977). Their existence in vivo is dependent not only upon the location and concentration of the complementary sequence but also upon the ribonucleoprotein organization of the transcripts. Photochemical cross-linking experiments have indicated that at least some double-stranded regions are authentic components of native hnRNA molecules and that these regions are relatively protein-free (Calvert and Pederson, 1979).

Although intramolecular duplexes could act as signal structures for the processing and transport of individual RNA molecules, the transcription of repetitive sequences into complementary sets distributed throughout the hnRNA population provides the means for a coordinate regulation of gene expression (reviewed, Davidson and Britten, 1979).

In this report we examine the properties of complementary repeat sequences which are contained in the RNA population derived from the nuclei (germinal vesicles) of amphibian oocytes. Oocytes have a special significance in RNA metabolism because a feature of these cells is to accumulate RNA sequences as stored maternal mRNA (reviewed, Davidson, 1976) and possibly also as nuclear-restricted RNA. Furthermore it has been reported that complementary repeat sequences are contained within most of the poly $(\mathrm{A})^{+}$ RNA of sea urchin eggs (Constantini et al., 1980) and of Xenopus eggs (Thomas et al., 1981) thus extending the presence of such sequences to a cytoplasmic location.

In this work we have utilized several advantages which derive from the use of amphibian oocytes: (1) Germinal vesicles can be rapidly handisolated without contamination with cytoplasmic components and without significant loss or degradation of nuclear RNA. (2) In selecting previtellogenic oocytes, any analysis of hnRNA molecules is uncomplicated by the transcription of rRNA sequences since nucleolar activity is negligible at this early oogenic stage. (3) By using amphibia with vastly different genome sizes (C-values) structural relationships can be studied by comparing the properties of RNA molecules transcribed from a series of increasingly complex genomes.

In addition, it has been shown previously that intermediately repetitive sequences are transcribed in the oocytes of Xenopus (Davidson and Hough, 1971) and Triturus (Sommerville and Malcolm, 1976). Here we show that either strand of such repeats can be transcribed to form complementary repeat sequences in different hnRNA molecules. The properties of complementary repeat sequences in amphibians of different $\mathrm{C}$-value are considered.

\section{Materials and Methods}

Animals and Labelling of Ovaries. Previtellogenic ovaries were dissected from immature females of the amphibian species Xenopus laevis, Triturus cristatus carnifex, Amphiuma means and Necturus maculosus. The ovaries were radioactively labelled by incubation at $18^{\circ} \mathrm{C}$ for $16 \mathrm{~h}$ 
in modified Barth's solution (Gurdon, 1974) containing $125 \mu \mathrm{Ci} / \mathrm{ml}$ each of: ${ }^{3} \mathrm{H}$-adenosine $(20 \mathrm{Ci} / \mathrm{mmol}) ;{ }^{3} \mathrm{H}$-cytidine $(29 \mathrm{Ci} / \mathrm{mmol}) ;{ }^{3} \mathrm{H}$-guanosine $(7 \mathrm{Ci} / \mathrm{mmol}) ;{ }^{3} \mathrm{H}$-uridine $(27 \mathrm{Ci} / \mathrm{mmol})$ and 500 units $/ \mathrm{ml}$ each of penicillin, streptomycin and kanamycin.

Preparation of $R N A$. Germinal vesicles were isolated manually from selected previtellogenic $(0.3-0.4 \mathrm{~mm})$ oocytes in Tris-buffered " $3: 1$ " solution $(75 \mathrm{mM} \mathrm{KCl}, 25 \mathrm{mM} \mathrm{NaCl}, 10 \mathrm{mM}$ Tris- $\mathrm{HCl}, \mathrm{pH} 7.2)$ and transferred immediately into ice-cold $70 \%$ ethanol. After collecting 100-200 nuclei, they were pelleted by centrifugation at $200 \mathrm{~g}$ for $2 \mathrm{~min}$. The drained pellet was raised in $0.2 \mathrm{ml}$ of a solution containing 1\% Sarkosyl NL-97 (Ciba-Geigy), $50 \mathrm{mM}$ Tris$\mathrm{HCl}, \mathrm{pH} 8.4,20 \mathrm{mM}$ EDTA and $0.5 \mathrm{mg} / \mathrm{ml}$ proteinase $\mathrm{K}$ (Boehringer, Mannheim: predigested at $37^{\circ} \mathrm{C}$ for $30 \mathrm{~min}$ ). The suspension was incubated at $18^{\circ} \mathrm{C}$ for $6-12 \mathrm{~h}$, then the RNA was isolated by a modification of the technique of Glison et al. (1974). Solid CsCl was added to $1 \mathrm{mg} / \mathrm{ml}$ and the solution was layered over $0.3 \mathrm{ml}$ of $5.7 \mathrm{M} \mathrm{CsCl}, 0.1 \mathrm{M}$ EDTA in a $1 \mathrm{ml}$ centrifuge tube. The RNA was pelleted through the $\mathrm{CsCl}$ cushion by centrifugation at $38,000 \mathrm{rpm}$ for $16 \mathrm{~h}$ at $25^{\circ} \mathrm{C}$ in an MSE $3 \times 5 \mathrm{ml}$ swing-out rotor equipped with adaptors for the small tubes. Then the bottoms of the tubes were cut off carefully, the pellet drained and the RNA resuspended in $5-50 \mu \mathrm{l}$ of $10 \mathrm{mM}$ Tris- $\mathrm{HCl}, \mathrm{pH} 7.2,1 \mathrm{mM}$ EDTA. By using this isolation procedure for vitellogenic oocytes, intact pre-ribosomal RNA molecules were identified routinely in electron microscopic preparations, indicating that the isolation procedure caused little degradation of RNA molecules.

Electron Microscopy. For preparations designed to show secondary structures in hnRNA, the spreading solution contained $0.5 \mathrm{M} \mathrm{NaCl}, 25 \%$ formamide $(4 \times$ recrystallized), $10 \mathrm{mM}$ Tris- $\mathrm{HCl}, \mathrm{pH} 8.5,1 \mathrm{mM}$ EDTA and $50 \mu \mathrm{g} / \mathrm{ml}$ cytochrome C. To remove secondary structures, yet retain intermolecular duplex structures, the spreading solution contained $80-95 \%$ formamide, $4 \mathrm{M}$ urea, $40 \mathrm{mM}$ Tris- $\mathrm{HCl}, \mathrm{pH} 8.5,1 \mathrm{mM}$ EDTA and $50 \mu \mathrm{g} / \mathrm{ml}$ cytochrome C. In order to denature completely base-paired structures, the RNA was heated to $60^{\circ} \mathrm{C}$ for $1 \mathrm{~min}$ in the formamide/urea solution. Spreading was on distilled water as hypophase and the RNA molecules were collected on parlodion-coated grids and processed for electron microscopy as described previously (Wellauer and Dawid, 1974).

Molecular Hybridization. In order to follow the formation of intramolecular and intermolecular duplex structures, hnRNA was first denatured by heating to $60^{\circ} \mathrm{C}$ for $1 \mathrm{~min}$ in $90 \%$ formamide, then chilled and the solution adjusted to $0.5 \mathrm{M} \mathrm{NaCl}, 10 \%$ formamide, $10 \mathrm{mM}$ Pipes, pH 6.4 and $1 \mathrm{mM}$ EDTA. The RNA concentration was established for each incubation and was generally in the range of $10-100 \mu \mathrm{g} / \mathrm{ml}$. Aliquots of 2,5 or $10 \mu \mathrm{l}$ were sealed in siliconized glass capillary tubes and incubated at $56^{\circ} \mathrm{C}$ for various times. RNA $\mathrm{C}_{0} \mathrm{t}$ values were calculated and corrected to $0.18 \mathrm{Na}^{+}$at $60^{\circ} \mathrm{C}$ as suggested by Britten et al. (1974) on the assumption that the correction is appropriate for RNA-RNA as well as RNA-cDNA reactions. The extent of duplex formation was assayed by digesting the RNA incubates with $20 \mu \mathrm{g}$ RNAase A, 2 units RNAase $T_{1}$ and 1 unit RNAase $T_{2}$ (all from Sigma Chemical Company) in $1 \mathrm{ml}$ of a solution of $0.2 \mathrm{~m} \mathrm{NaCl}, 0.1 \mathrm{M}$ Tris- $\mathrm{HCl}, \mathrm{pH} 7.2$ and $1 \mathrm{mM}$ EDTA. For digestions, the RNA concentration was adjusted to $20 \mu \mathrm{g} / \mathrm{ml}$ using E. coli tRNA (Bochringer, Mannheim) and the total mixture was incubated at $30^{\circ} \mathrm{C}$ for $10 \mathrm{~min}$. RNAase-resistant material was coprecipitated with $50 \mu \mathrm{g}$ bovine serum albumin using $10 \%$ trichloroacetic acid and collected and washed on Millipore HAWP filters. Radioactivity of the dried filters was assayed by liquid scintillation counting.

RNA-DNA hybridization was performed as described previously (Sommerville and Malcolm, 1976) using DNA isolated from either Triturus or Necturus testes and sheared to $400-800$ bp lengths. Double-stranded RNA was isolated after RNAase digestion of hnRNA that had been annealed to an RNA $\mathrm{C}_{0} \mathrm{t}$ of $20 \mathrm{Mol} \cdot \mathrm{sec}$. The RNAase-resistant material was treated with proteinase K and "phenol" extracted (Sommerville and Malcolm, 1976).

In situ Hybridization. Iodinated dsRNA fragments were denatured by heating to $60^{\circ} \mathrm{C}$ for $2 \mathrm{~min}$ in $62.5 \%$ formamide and hybridized to lampbrush chromosome preparations in $50 \%$ formamide, $4 \times \mathrm{SSC}$ ( $\mathrm{SSC}$ is: $0.15 \mathrm{M} \mathrm{NaCl}, 0.015 \mathrm{M}$ sodium citrate, $\mathrm{pH} 7.2$ ) at $37^{\circ} \mathrm{C}$ for $16 \mathrm{~h}$. About $20 \mathrm{ng}\left(10^{5}\right.$ counts $\left./ \mathrm{min}\right)$ dsRNA in a volume of $20 \mu \mathrm{l}$ were used in each reaction. 
Controls were run with non-denatured dsRNA. Lampbrush chromosomes were prepared from Triturus oocytes and autoradiographs were made after hybridization as described previously (Old et al., 1977). Controls of lampbrush chromosome preparations which had been previously treated for $1 \mathrm{~h}$ at $37^{\circ} \mathrm{C}$ with the RNAase cocktail described above were also used.

\section{Results}

\section{Electron Microscopic Analysis of Intermolecular Duplex Structures}

Germinal vesicles were hand isolated from previtellogenic oocytes of various amphibians and hnRNA was extracted by a procedure that minimizes molecular degradation. The individual RNA preparations were then examined by electron microscopy. Molecular lengths were determined by contour length analysis of molecules spread under denaturing conditions. These data are summarized in Table 1 and show that the length distributions are not very much different for the hnRNA extracted from organisms with largely different $\mathrm{C}$-values and, in fact, are similar to the length distribution previously published for hnRNA from HeLa cells (Fedoroff et al., 1977). The relationship between $\mathrm{C}$-value, transcript length and hnRNA length in amphibian oocytes indicates that there is extensive processing of RNA within the long ribonucleoprotein fibrils seen in Miller spreads (Scheer and Sommerville, 1982).

The RNA molecules were examined further after various treatments: immediately after the isolation step of pelleting through $5.7 \mathrm{M} \mathrm{CsCl}$; after heat denaturation; and after incubation of denatured RNA under conditions favouring base-pairing. In Triturus hnRNA, extensive secondary structure is seen in the newly isolated molecules on spreading from non-denaturing $(0.5 \mathrm{M} \mathrm{NaCl} / 25 \%$ formamide) solutions. In addition to the many hairpin and stem-loop structures already described (Malcolm and Sommerville, 1977; Sommerville and Scheer, 1981) complexes of two or more molecules are frequently seen. As previously recommended (Fedoroff et al., 1977) RNA molecules can be treated to lose most of their intrastrand secondary structure, yet retain their intermolecular association, by spreading from a

Table 1. Contour length analysis of hnRNA molecules isolated from the germinal vesicles of various amphibia

\begin{tabular}{|c|c|c|c|c|c|}
\hline \multirow[t]{2}{*}{ Organism } & \multirow{2}{*}{$\begin{array}{l}\text { C-value } \\
\text { (pg) }\end{array}$} & \multirow{2}{*}{$\begin{array}{l}\text { Molecules } \\
\text { measured } \\
\text { (number) }\end{array}$} & \multicolumn{3}{|c|}{ hnRNA length $(\mu \mathrm{m})$} \\
\hline & & & Range & $\begin{array}{l}\text { Number } \\
\text { average }^{\text {a }}\end{array}$ & $\begin{array}{l}\text { Weight } \\
\text { average }^{\text {b }}\end{array}$ \\
\hline Xenopus laevis & 3 & 448 & $0.1-6.7$ & 0.57 & 0.64 \\
\hline Triturus cristatus & 23 & 482 & $0.1-10.1$ & 1.69 & 2.10 \\
\hline Amphiuma means & 65 & 295 & $0.1-6.8$ & 1.03 & 1.19 \\
\hline Necturus maculosus & 78 & 790 & $0.1-6.2$ & 1.04 & 1.17 \\
\hline
\end{tabular}

a Total contour length divided by number of molecules measured

b Length of the molecule with $50 \%$ of RNA mass in longer molecules when arranged as a series of increasing length 
hyperphase containing $90 \%$ formamide and $4.5 \mathrm{M}$ urea. Under these conditions intermolecular duplex regions can be clearly recognized and characterized. On spreading the hnRNA molecules soon after heat denaturation, the interstrand duplexes are no longer seen, although intrastrand secondary structures rapidly reform and can be seen if the molecules are spread from low formamide/urea. On incubating the denatured RNA in the presence of $0.5 \mathrm{M} \mathrm{NaCl} / 10 \%$ formamide at $56^{\circ} \mathrm{C}$, there is a progressive increase in the percentage of RNA molecules involved in interstrand duplex structures. For example, Triturus hnRNA, at an initial concentration of $45 \mu \mathrm{g} / \mathrm{ml}$, shows few intermolecular duplex structures after a few min incubation, whereas most of the molecules are involved in duplex forms after $24 \mathrm{~h}$. This is the effect expected of rapidly associating complementary sequences.

Several important differences are noted in the intermolecular associations of hnRNA isolated from different genera of amphibia. Compared with Triturus oocyte hnRNA (Fig. 1 b and c), intermolecular duplex structures are less evident in the hnRNA from Necturus oocytes. Some of these variations may be due to differences in the stability of base-paired regions under the stringent spreading conditions used. (A more quantitative description of the extent of duplex formation is given by the molecular hybridization experiments described later.).

In newly isolated Triturus hnRNA, spread from $95 \%$ formamide $/ 4 \mathrm{M}$ urea, the base-paired regions are mostly fairly short $(0.05-0.10 \mu \mathrm{m})$, although classes of longer length $(0.2-0.4 \mu \mathrm{m}$ and $0.7-0.9 \mu \mathrm{m})$ are not unusual (Fig. $1 \mathrm{a}$ and b). However, denatured and renatured hnRNA, spread from $95 \%$ formamide $/ 4 \mathrm{M}$ urea, shows only longer base-paired regions (Fig. $1 \mathrm{~d}$ and e) with length ranges of $0.2-0.4 \mu \mathrm{m}$ and $0.7-0.9 \mu \mathrm{m}$. It may be concluded that the renaturation conditions are particularly favourable for the formation of stable duplex structures and that certain of the complementary repeat sequence lengths may not be base-paired in vivo.

Of the other amphibia, the duplex regions in Xenopus hnRNA are short $(0.04-0.20 \mu \mathrm{m}$, Fig. $2 \mathrm{a})$ and the duplex regions in Necturus hnRNA are generally long (covering a wide range of $0.1-2.6 \mu \mathrm{m}$, Fig. $2 \mathrm{~b}-\mathrm{d}$ ). Although long regions of continuous base-pairing are seen (Fig. $2 \mathrm{~b}$ ), many of the duplex structures of Necturus hnRNA are complex in their organization, with periodic bubbles indicative of intervening $(\mathrm{A}+\mathrm{U})$ rich, or non-homologous, stretches along their length (Fig. $2 \mathrm{c}$ and d). Also, aggregates of more than two molecules are found (Fig. $2 \mathrm{~b}$ and d). Multimolecular complexes and bubble structures are occasionally seen in Triturus hnRNA (Fig. $1 \mathrm{~b}$ and d). Amphiuma hnRNA contains duplex structures in the range of $0.08-2.02 \mu \mathrm{m}$.

The number average values for duplex length in untreated RNA are Xenopus, $0.11 \mu \mathrm{m}$; Triturus, $0.26 \mu \mathrm{m}$; Amphiuma, $0.28 \mu \mathrm{m}$; Necturus, $0.86 \mu \mathrm{m}$. Some of the intermolecular duplex length data are summarized in Figure 3. Two points are worth considering. First, the duplex lengths are non-random and fall into distinct size classes. Second, on comparing the duplex lengths with the hnRNA molecular lengths (Table 1), it appears that whereas the average hnRNA lengths show no increasing trend with 


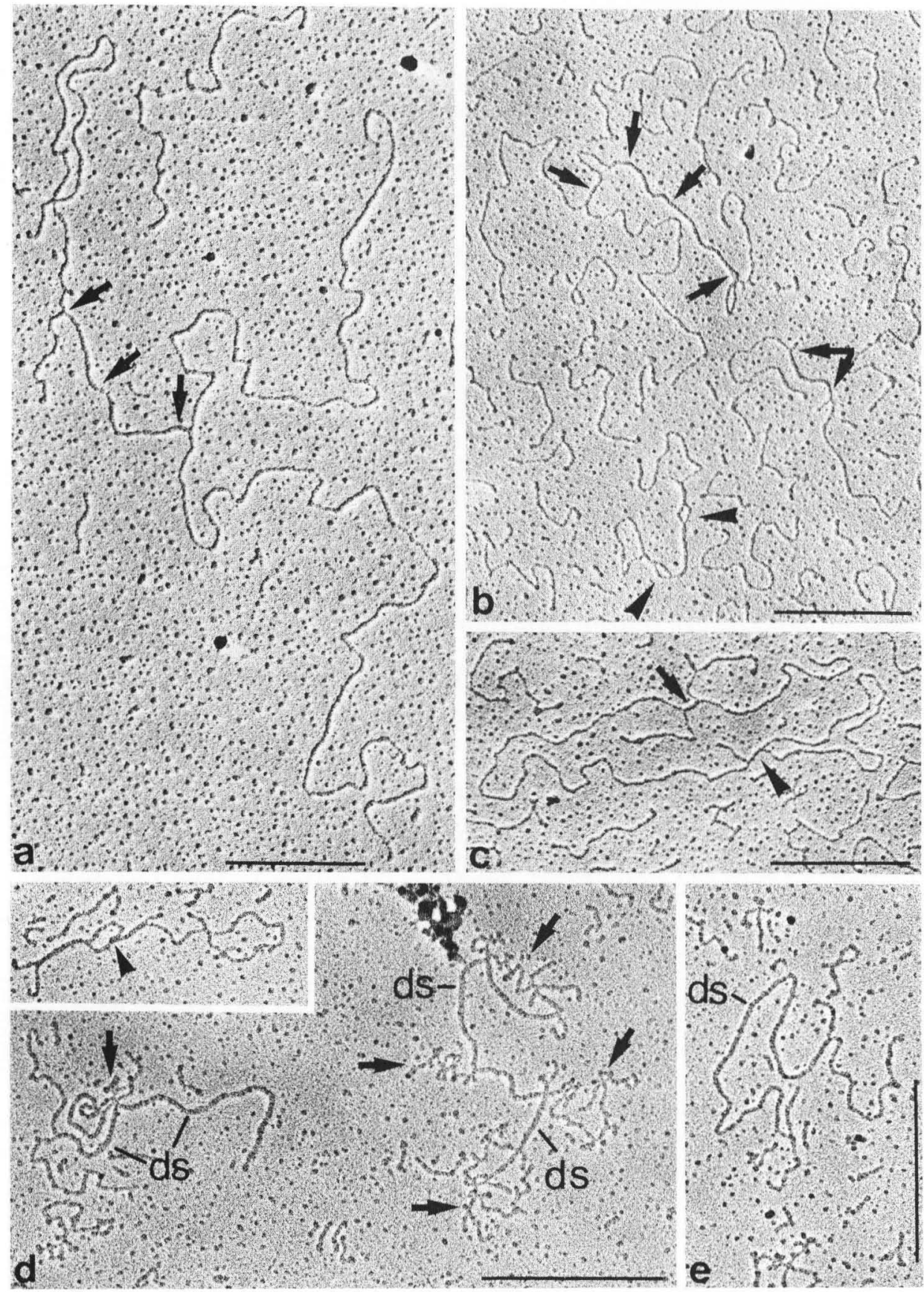

Fig. 1 a-e. Electron micrographs of intermolecular duplex structures seen in spread preparations of Triturus oocyte hnRNA. a-c hnRNA molecules spread after isolation and without further treatment from 95\% formamide, $4 \mathrm{M}$ urea. Arrows denote double-stranded regions formed between molecules. Arrowheads in (b) indicate "bubbles" in the ds region, arrowhead in (c) points to an intramolecular double-stranded region. d and e hnRNA molecules which have been heat-denatured, renatured for $24 \mathrm{~h}$ (equivalent to an $\mathrm{RNA} \mathrm{C}_{0} \mathrm{t}$ value of $50 \mathrm{Mol} \cdot \mathrm{sec}$ ) and spread from 95\% formamide, $4 \mathrm{M}$ urea. Double-stranded regions are denoted by ds, single-stranded bush-like formations by arrows. Insert in (d) shows a "bubble" in a ds region. The bars represent $0.5 \mu \mathrm{m}$ 


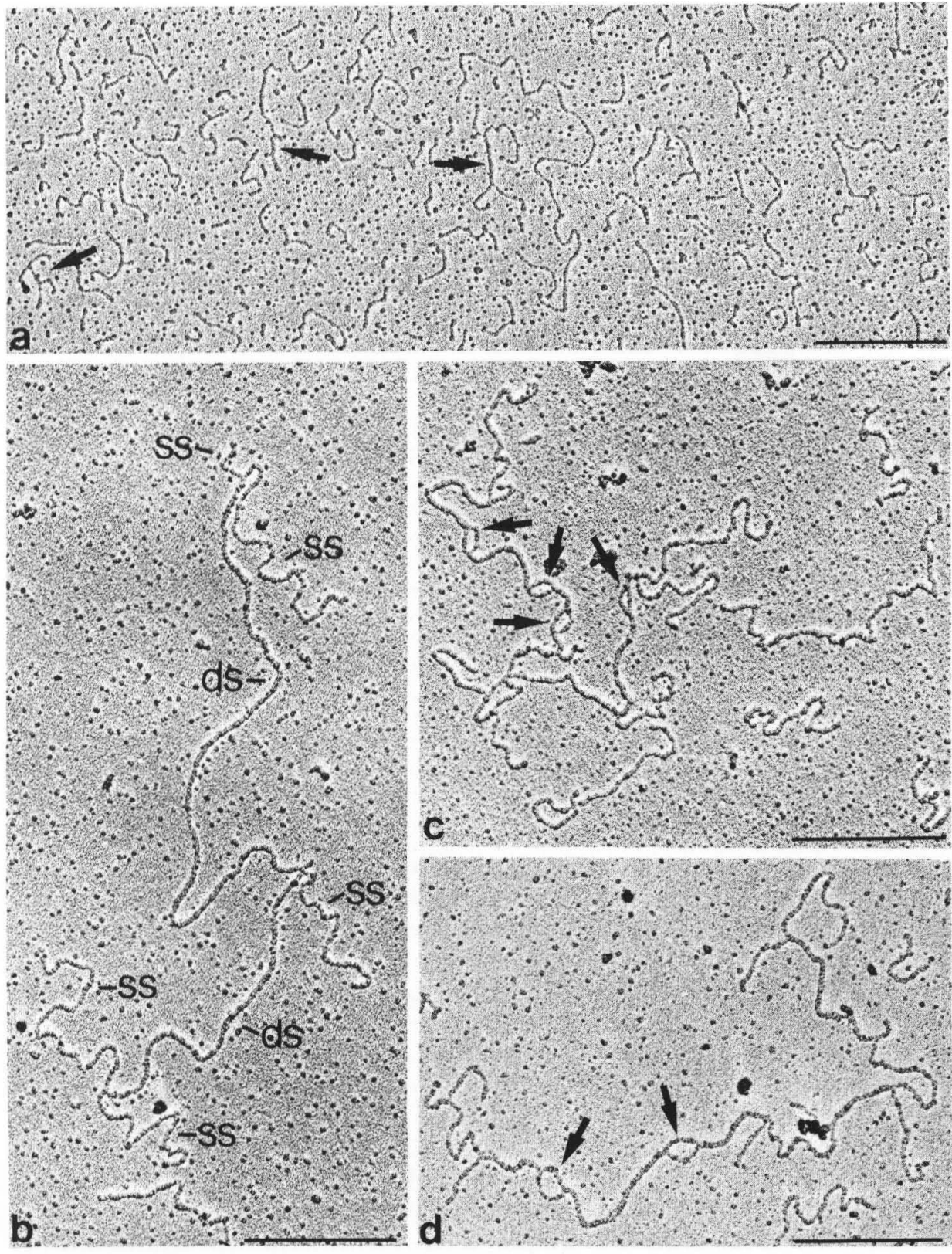

Fig. 2a-d. Electron micrographs of intermolecular duplex structures seen in spread preparations of Xenopus oocyte hnRNA and Necturus oocyte hnRNA. a Xenopus oocyte hnRNA spread from $80 \%$ formamide, $4 \mathrm{M}$ urea without further treatment. Arrows indicate intermolecular duplex structures. b-d Necturus oocyte hnRNA spread from $90 \%$ formamide, $4 \mathrm{M}$ urea without further treatment. Note the long double-stranded regions $(d s)$ with relatively short singlestranded $(s s)$ tails. Arrows in $\mathbf{c}$ and $\mathbf{d}$ denote "bubbles". The bars represent $0.5 \mu \mathrm{m}$ 


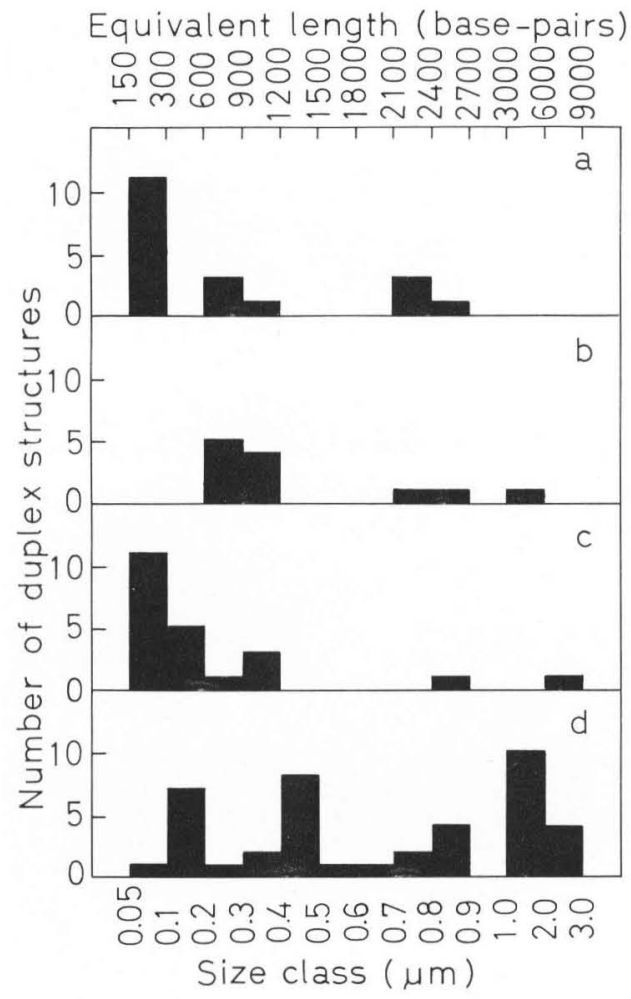

Fig. 3. Length distribution of intermolecular duplex structures seen in hnRNA isolated from the germinal vesicles of various amphibia. a Triturus hnRNA, untreated. b Triturus hnRNA, denatured and renatured to an $\mathrm{RNA} \mathrm{C}_{0} \mathrm{t}$ value of $50 \mathrm{Mol} \cdot \mathrm{sec}$. c Amphiuma hnRNA, untreated. d Necturus hnRNA, untreated

increasing $\mathrm{C}$-value, the average lengths of complementary repeat sequences show some increase with C-value (at least within the series Xenopus - Triturus - Necturus) to the extent that in many of the hnRNA molecules from Necturus oocytes most of their length is involved in base-pairing (Fig. $2 \mathrm{~b}$ to d).

In all of the genera examined, the duplex regions show no preferred location within the hnRNA molecules.

\section{Kinetics of Rapid Formation of RNA Duplex Structures}

More accurate information on the extent and rate of RNA duplex formation was obtained by using labelled hnRNA for molecular hybridization and assaying the percentage of radioactivity which remains acid precipitable after ribonuclease digestion. It is known that in Triturus oocytes there is transcription of homopolymeric and simple repeat sequences (Callan and Old, 1980; Varley et al., 1980) and to include all such sequences in the assay all four nucleosides were used in labelled form. The labelled hnRNA was then incubated, at known concentration for various periods, under conditions favouring RNA annealing and the progress of the formation of double-stranded structures was measured after treatment of the products with a cocktail of ribonucleases $A, T_{1}$ and $T_{2}$. The kinetics of RNA duplex 


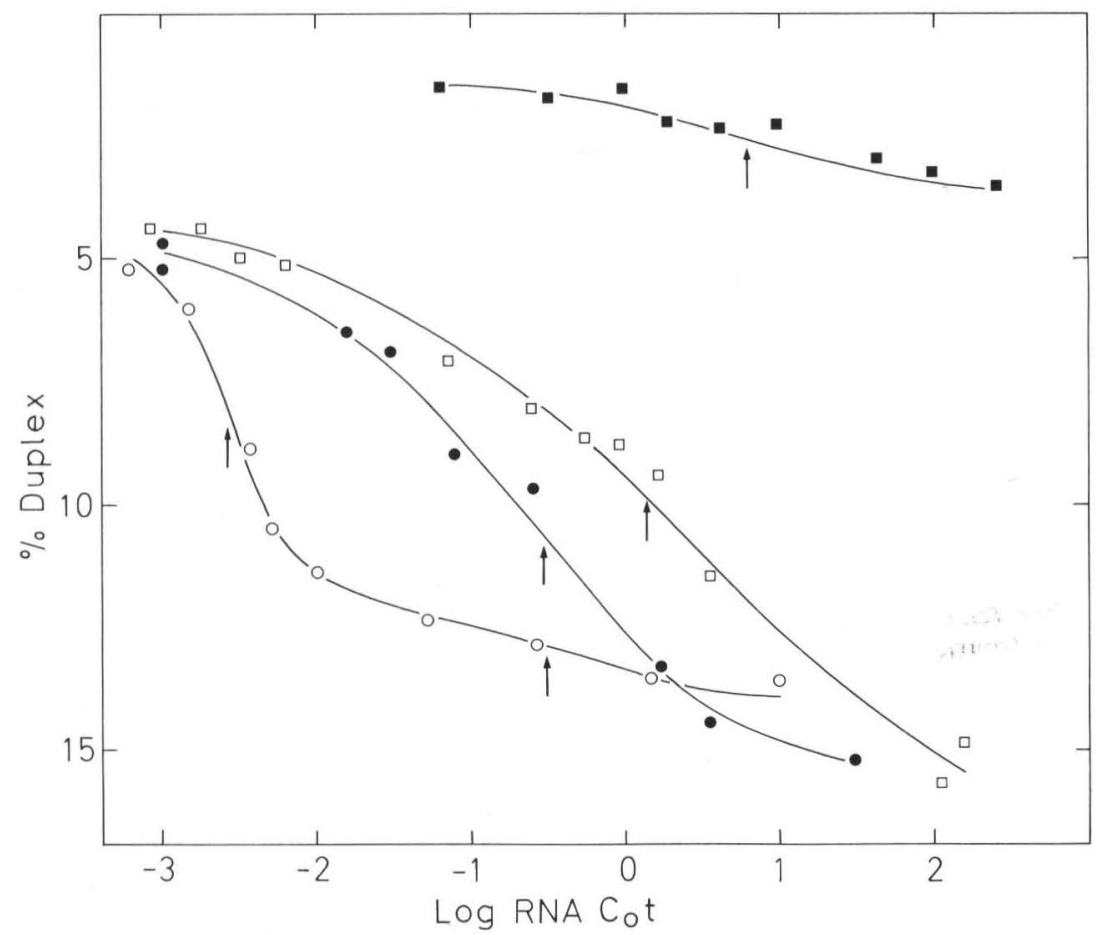

Fig. 4. Kinetics of formation of intermolecular duplex structures in hnRNA isolated from the germinal vesicles of various amphibia. The ${ }^{3} \mathrm{H}$-labelled hnRNA was heat-denatured and incubated in $0.5 \mathrm{M} \mathrm{NaCl}, 10 \%$ formamide, $10 \mathrm{mM}$ Pipes, $\mathrm{pH} 6.4,1 \mathrm{mM}$ EDTA at $56^{\circ} \mathrm{C}$. RNA $\mathrm{C}_{0}$ t values were calculated and corrected to $0.18 \mathrm{M} \mathrm{Na}^{+}$at $60^{\circ} \mathrm{C}$ as outlined by Britten et al. (1974). The extent of duplex formation was assayed by determining the percentage of acid precipitable radioactivity resistant to ribonuclease digestion as described in Materials and Methods. The reaction kinetics of Xenopus $(\mathrm{O}-\mathrm{O})$, Triturus $(\bullet-$ Amphiuma $(\mathbf{\square}-\mathbf{\square})$

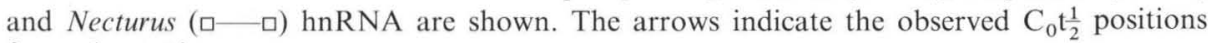
for each reaction

formation for hnRNA extracted from oocytes of various amphibia is expressed in the form of standard $\mathrm{C}_{0} \mathrm{t}$ plots (Fig. 4), where RNA $\mathrm{C}_{0} \mathrm{t}$ is the initial RNA concentration in moles nucleotide per litre $\times$ time in seconds $(\mathrm{Mol} \cdot \mathrm{sec})$. In all of the reactions at least two components are seen: a zerotime component which represents the extent of formation of intramolecular secondary structures and a kinetically more complex component which represents the extent of formation of intermolecular duplex structures. This interpretation was confirmed by comparing the increase in ribonuclease resistance with the structural state of the RNA as revealed by electron microscopy (as shown in Figs. 1 and 2).

The percentage of radioactive RNA involved in the formation of intrastrand secondary structures is similar for Xenopus $(4.5 \%)$, Triturus $(4.7 \%)$ and Necturus $(4.4 \%)$ but different for Amphiuma (1.4\%). The value for Xenopus is more difficult to estimate because of a very rapid reaction which could be due to the interaction of complementary sequences of low complex- 
ity with one of the complementary strands present at a higher concentration than the other.

The main kinetic transition seen in the formation of ribonuclease-resistant material differs for the different amphibia, both in the percentage of RNA sequence involved and in the rate of the reaction. The percentage of hnRNA radioactivity which interacts over the range of $\mathrm{RNA} \mathrm{C}_{0} \mathrm{t}$ $10^{-3}-10^{2} \mathrm{Mol} \cdot \mathrm{sec}$ is $10.7 \%$ for Triturus and $12.1 \%$ for Necturus but only $2.2 \%$ for Amphiuma. Xenopus hnRNA shows two component reactions; the first, very fast, reaction involving $7.2 \%$ of the hnRNA, the second reaction involving $2.5 \%$ of the hnRNA. Therefore this group of values shows neither constancy nor any relationship with C-value. Because of RNA breakdown during incubation and limitations of the assay procedure, the percentage duplex values should be considered as minimum estimates. For instance, in the annealing of ${ }^{3} \mathrm{H}$-labelled polyuridylic acid with polyadenylic acid under similar conditions, only $74 \%$ of the input radioactivity is recovered in duplex form. Therefore the total percentage of RNA mass capable of forming intermolecular duplex structures could be as high as $16.4 \%$ for Necturus hnRNA.

The half-rates of the RNA annealing reactions are a measure of the sequence complexity of the complementary repeats. Although the reaction kinetics do not fit ideal second-order curves, presumably due to heterogeneity in the relative abundance of different sequences, the half rates (RNA $\mathrm{C}_{0} \mathrm{t} \frac{1}{2}$ ) represent approximate average values. As can be seen from Fig. 4 the half rates are different for the different amphibia. However the kinetics shown are based on the initial concentration of total RNA and the rate values have to be corrected for the effective concentration of complementary repeat sequences alone and for RNA duplex length. The corrected RNA $\mathrm{C}_{0} \mathrm{t} \frac{1}{2}$ values are $2.2 \times 10^{-4} \mathrm{M} \cdot \mathrm{sec}$ and $9.0 \times 10^{-3} \mathrm{M} \cdot \mathrm{sec}$ for Xenopus, $5.6 \times 10^{-2} \mathrm{M} \cdot \mathrm{sec}$ for Triturus, $2.6 \times 10^{-1} \mathrm{M} \cdot \mathrm{sec}$ for Amphiuma and $4.2 \times 10^{-1} \mathrm{M} \cdot \mathrm{sec}$ for Necturus (Table 2). Therefore, to a first approximation, the rate of duplex formation appears to be inversely related to $\mathrm{C}$-value. However, as already shown, the length of individual interstrand duplex structures also tends to increase with $\mathrm{C}$-value. Therefore the increase in sequence complexity noted here may be accounted for by an increase in length of complementary repeats rather than an increase in the number of different kinds of complementary repeats.

The formation of duplex structures has also been examined in the hnRNA from amphibian culture cells (not shown). The kinetics for Triturus and Xenopus culture cell hnRNA are similar to those for the corresponding oocyte hnRNAs. For instance, the corrected RNA $\mathrm{C}_{0} \mathrm{t}$ value for Triturus culture cell hnRNA is $5.3 \times 10^{-2}$ which is similar to the oocyte value. A rate value for Xenopus hnRNA is again difficult to determine because of the more rapid and complex kinetics. On the basis of this limited comparison, the transcription of complementary repeat sequences appears not to be restricted to oocytes and appears to involve similar levels of sequence complexity in both somatic and germ-line cells. 
Table 2. Analysis of formation of duplex structures in the hnRNA from amphibian oocytes

\begin{tabular}{|c|c|c|c|c|c|}
\hline \multirow[t]{2}{*}{ Organism } & \multirow{2}{*}{$\begin{array}{l}\text { Intramolecular } \\
\text { duplex } \\
\% \text { RNA } \\
\text { radioactivity }\end{array}$} & \multicolumn{4}{|c|}{ Intermolecular duplex } \\
\hline & & $\begin{array}{l}\% \mathrm{RNA} \\
\text { radio- } \\
\text { activity }\end{array}$ & $\begin{array}{l}\text { Average } \\
\text { length } \\
(\mu \mathrm{m})\end{array}$ & $\begin{array}{l}\text { RNA } C_{0} t_{1 / 2} \\
\text { (observed) }\end{array}$ & $\begin{array}{l}\mathrm{RNA} \mathrm{C}_{0} \mathrm{t}_{1 / 2} \\
\text { (corrected) }^{\mathrm{a}}\end{array}$ \\
\hline Xenopus & 4.5 & $\begin{array}{l}7.2 \\
2.5\end{array}$ & 0.11 & $\begin{array}{l}2.8 \times 10^{-3} \\
3.6 \times 10^{-1}\end{array}$ & $\begin{array}{l}2.2 \times 10^{-4} \\
9.0 \times 10^{-3}\end{array}$ \\
\hline Triturus & 4.7 & 10.7 & 0.26 & $3.4 \times 10^{-1}$ & $5.6 \times 10^{-2}$ \\
\hline Amphiuma & 1.4 & 2.2 & 0.28 & $7.2 \times 10^{0}$ & $2.6 \times 10^{-1}$ \\
\hline Necturus & 4.4 & 12.1 & 0.86 & $1.3 \times 10^{0}$ & $4.2 \times 10^{-1}$ \\
\hline
\end{tabular}

a The rates are adjusted to directly comparable values by correcting for the percentage of radioactivity involved in duplex formation and the average effective length of complementary sequences, using Xenopus 200-300 bp lengths as a standard, as outlined by Britten et al. (1974)

It has been noted already that many of the interstrand duplex structures are stable under conditions of spreading ( $90 \%$ formamide $/ 4.5 \mathrm{M}$ urea) that disrupt most of the hnRNA secondary structures. This difference in stability can be attributed to several factors, primarily the $(\mathrm{G}+\mathrm{C})$ content, the relative lengths of the repeat sequences and the extent of matching of the basepaired regions. A more quantitative description of the stability characteristics of double-stranded polynucleotides is given by their thermal melting profiles. Because both secondary structures and repeats capable of interstrand association occur in the same molecules, it is difficult to separate the two types of duplex for thermal stability studies. Since the proportion of RNA forming secondary structures is relatively low for the hnRNA from Triturus culture cells and Amphiuma oocytes, double stranded RNA was isolated from these sources and used for thermal stability studies. Basically, radioactively labelled hnRNA was annealed to RNA $\mathrm{C}_{0} \mathrm{t}$ value of $5 \times 10^{2} \mathrm{Mol} \cdot \mathrm{sec}$, digested with ribonuclease, phenol-extracted and applied to a column of hydroxylapatite. The radioactively labelled RNA was then eluted from the column with $0.1 \times \mathrm{SSC}$ at temperature increments of $5^{\circ} \mathrm{C}$. The melting profiles of Triturus and Amphiuma double-stranded RNA (dsRNA) are shown in Figure 5. In these and other melts there is a biphasic profile with an early elution of radioactive material which has a $T_{m}$ value of about $65^{\circ} \mathrm{C}$ and a later fraction with a $\mathrm{T}_{\mathrm{m}}$ value in the range $82-85^{\circ} \mathrm{C}$ $\left(\mathrm{T}_{\mathrm{m}}=83^{\circ} \mathrm{C}\right.$ for Triturus dsRNA; $\mathrm{T}_{\mathrm{m}}=84^{\circ} \mathrm{C}$ for Amphiuma dsRNA). Because of the relative proportions of radioactivity in the two fractions, and because of the electron microscopic observations on the relative instability of secondary structures, it seems likely that the early elution is of short dsRNA that existed primarily in the form of secondary structures, the later elution being derived from the longer interstrand complexes. The stable nature of the intermolecular duplex structures indicates that the sequences constituting each family of inverted repeats are well conserved. 


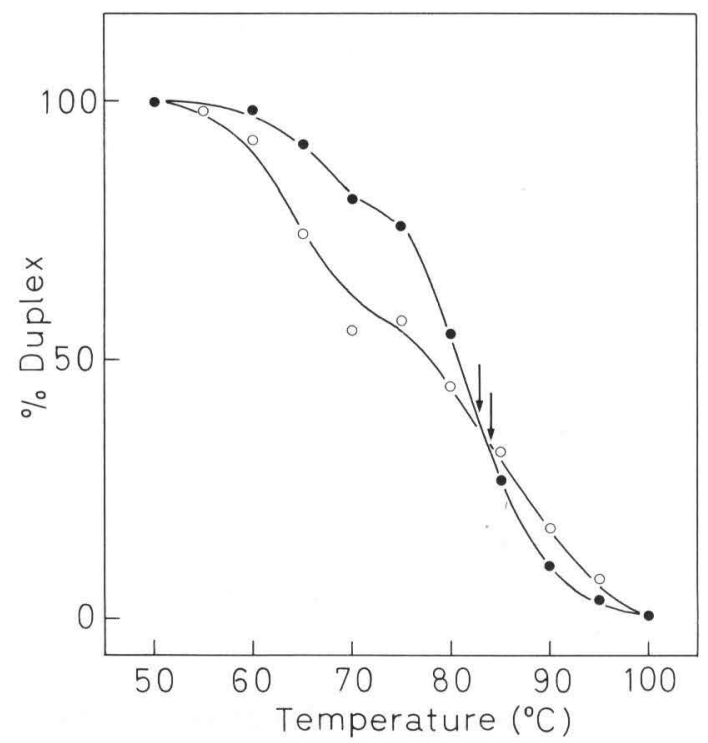

Fig. 5. Thermal stability of double-stranded RNA isolated from renatured hnRNA. ${ }^{3} \mathrm{H}$-labelled hnRNA extracted from Triturus culture cells (•-) and Amphiuma oocytes (o-O) was renatured to an RNA $\mathrm{C}_{0}$ t value of $20 \mathrm{Mol} \cdot \mathrm{sec}$. Single-stranded regions were digested with ribonuclease and the dsRNA was phenol extracted, precipitated with ethanol and raised in $0.1 \times \mathrm{SSG}$. The labelled dsRNA was eluted from columns of hydroxylapatite by increasing the temperature in $5^{\circ} \mathrm{C}$ increments. The arrows indicate the $\mathrm{T}_{\mathrm{m}}$ values of the second, major, transition

\section{Genetic Frequency and Species Specificity} of Complementary Repeat Sequences

In order to estimate the average representation of each type of complementary repeat sequence in the genome, radioactively labelled dsRNA was denatured and hybridized with a vast excess of denatured DNA. The extent of hybrid formation was assayed by ribonuclease digestion and the rate was plotted as a standard $\mathrm{C}_{0} \mathrm{t}$ curve (Fig. 6). Due to the 50,000 fold excess of DNA, RNA-DNA hybridization occurs preferentially, although eventually RNA-RNA association occurs as shown by the Triturus RNA alone plot. Although the reaction kinetics are incomplete, the rate of hybridization of Triturus dsRNA with Triturus DNA is estimated to be $\mathrm{C}_{0} \mathrm{t}_{1 / 2}=1.2 \times$ $10^{1} \mathrm{Mol} \cdot \mathrm{sec}$ (observed $\mathrm{C}_{0} \mathrm{t}_{1 / 2}$ of 20 corrected for $60 \%$ reaction). Since the expected rate of reassociation of the single-copy sequences of Triturus DNA is $\mathrm{C}_{0} \mathrm{t}_{1 / 2}=3 \times 10^{4} \mathrm{Mol} \cdot \mathrm{sec}$ (Sommerville and Malcolm, 1976), the complementary sequences transcribed into hnRNA would appear to be present in the genome with a repeat frequency of a few thousand.

The hybridization of Necturus oocyte dsRNA sequences with Necturus DNA shows kinetics similar to those of the Triturus reaction, indicating that the average repeat frequency is greater in Necturus than in Triturus, apparently by a number proportional to the increase in genome size. Data 


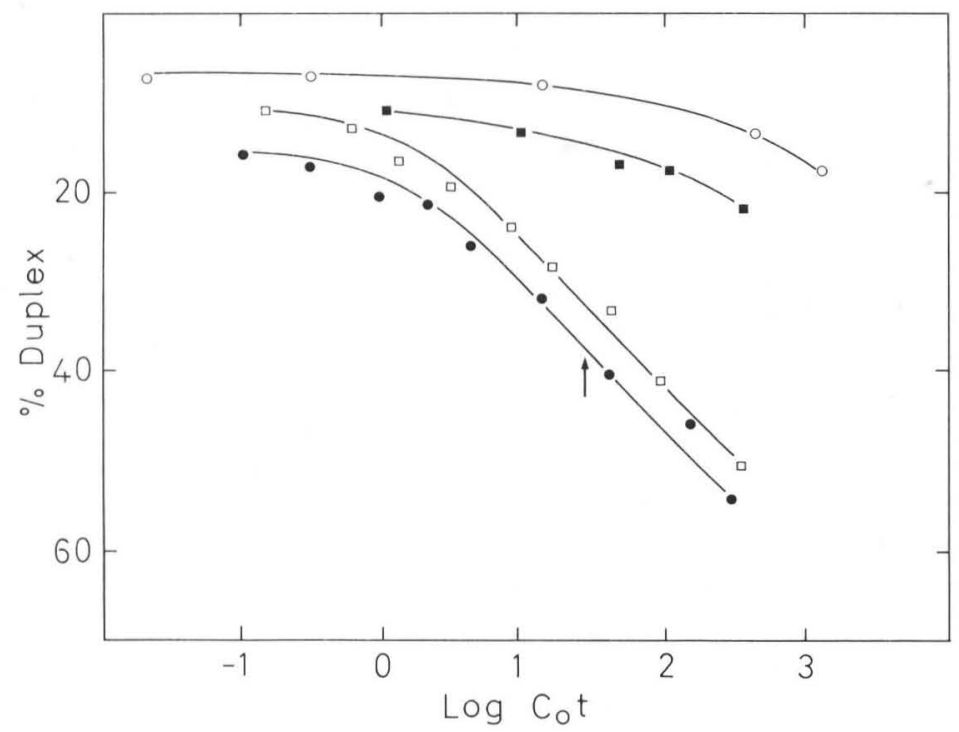

Fig. 6. Kinetics of hybridization of complementary repeat RNA sequences with DNA. ${ }^{3} \mathrm{H}-$ labelled dsRNA was prepared from oocyte hnRNA as described for Figure 5. The labelled dsRNA was mixed with excess DNA, heat denatured and incubated at $62^{\circ} \mathrm{C}$ in $0.18 \mathrm{M} \mathrm{NaCl}$, $10 \mathrm{mM}$ Pipes, pH 6.4, $1 \mathrm{mM}$ EDTA. Each reaction tube contained $120 \mathrm{ng}$ dsRNA (equivalent to approximately 6,000 counts $/ \mathrm{min}$ ) and $40-172 \mu \mathrm{g}$ DNA in a volume of $100 \mu \mathrm{l}$. Triturus dsRNA sequences were hybridized with Triturus DNA (- - ) and Necturus dsRNA sequences were hybridized with Necturus DNA ( $\square-\square)$ and with Triturus DNA (- - a). As a control to estimate the rate of RNA-RNA reassociation Triturus dsRNA was incubated with Escherichia coli DNA ( $\left.\mathrm{O}_{-} \mathrm{O}\right)$. The $\mathrm{C}_{0} \mathrm{t} \frac{1}{2}$ value of the homologous reactions is indicated by an arrow

was difficult to obtain for the repeat frequency of complementary sequences of other amphibians and consequently no generalization can be made about the relationship between repeat frequency and $\mathrm{C}$-value. However, it is interesting to note that other types of genetic sequence, notably ribosomal RNA genes, 5S RNA genes, tRNA genes and histone genes, do tend to increase in number proportionately with C-value (Sommerville, 1979).

It has already been argued that on the basis of thermal stability there is sequence conservation within each family of repeat. In order to determine whether such sequences are conserved between genera, denatured dsRNA was reacted with heterologous DNA. As can be seen from Figure 6, the reaction of Triturus RNA with Necturus DNA is less than 5\% of the homologous Triturus/Triturus reaction. Therefore the highly repetitive sequences capable of forming interstrand duplex structures are not the same in these two different genera of amphibia.

\section{Location of Complementary Repeat Sequences in hnRNA Molecules and in the Genome}

A significant proportion of the hnRNA population consists of molecules that are polyadenylated at their $3^{\prime}$ ends and it is proposed that these molecules 
Table 3. Binding of ${ }^{3} \mathrm{H}$-uridine-labelled hnRNA to oligo (dT) cellulose

\begin{tabular}{lcc}
\hline Treatment & \multicolumn{2}{c}{ Radioactivity bound (\%) } \\
\cline { 2 - 3 } & Experiment 1 & Experiment 2 \\
\hline None & 14.0 & 18.3 \\
Denatured & 4.7 & 6.2 \\
Renatured to RNA C $\mathrm{C}_{0} \mathrm{t} 20 \mathrm{Mol} \cdot \mathrm{sec}$ & 28.1 & 26.4 \\
\hline
\end{tabular}

are precursors of poly (A) ${ }^{+}$mRNA (reviewed, Darnell, 1979). If complementary repeat sequences are important signals for some aspect of premessenger activity then it might be expected that they should be localized in the same hnRNA molecules that carry polyadenylated tails. This suggestion was checked by measuring the extent to which radioactively-labelled hnRNA was bound to oligo(dT) cellulose affinity columns after heat denaturation and reassociation steps. Triturus hnRNA, labelled in vitro with ${ }^{3} \mathrm{H}$-uridine, was extracted from isolated germinal vesicles, as already described, and assayed for the percentage of radioactivity bound specifically to oligo(dT). A second aliquot of labelled hnRNA was assayed in this same way immediately after denaturation by heating to $100^{\circ} \mathrm{C}$ for $2 \mathrm{~min}$, while a third was assayed after denaturation and subsequent incubation under conditions favouring the formation of molecular hybrids. The results indicate (Table 3) that, if ${ }^{3} \mathrm{H}$-uridine labelling is randomly distributed, about $5 \%$ of the hnRNA sequences are polyadenylated, whereas after reassociation to an RNA $\mathrm{C}_{0} \mathrm{t}$ value of $20 \mathrm{Mol} \cdot \mathrm{sec}$, the amount of RNA bound by oligo(dT) increases to over $26 \%$. The most obvious reason for this increase is that poly $(\mathrm{A})^{+}$hnRNA molecules contain complementary repeat sequences which can interact with repeats on poly $(\mathrm{A})^{-}$molecules to form multimolecular complexes which are bound by oligo(dT). As already discussed, interstrand duplex structures are present in hnRNA molecules isolated from $\mathrm{CsCl}$ gradients, thus accounting for the initial high percentage of binding to oligo (dT).

If complementary repeat sequences are contained in a large proportion of the hnRNA molecules, it would be predicted that they are located within the genome at widely distributed sites. That this is indeed the case can be demonstrated by hybridization of dsRNA sequences to DNA restriction fragments or to chromosome preparations.

Triturus dsRNA was prepared by isolating germinal vesicle hnRNA, reassociating this to an $\mathrm{RNA} \mathrm{C}_{0} \mathrm{t}$ value of $20 \mathrm{Mol} \cdot \mathrm{sec}$, digesting singlestrand regions with ribonuclease and labelling the duplex regions to high specific activity by iodination. When the ${ }^{125}$ I-labelled dsRNA was reacted with gel transfers of EcoRI digested Triturus DNA (Southern, 1975) the RNA was found to hybridize across the whole smear of DNA fragment sizes (not shown). From this observation it can be concluded that the population of complementary sequences is dispersed throughout the genomic DNA, but what of their expression in RNA transcripts? When the same ${ }^{125} \mathrm{I}$ - 

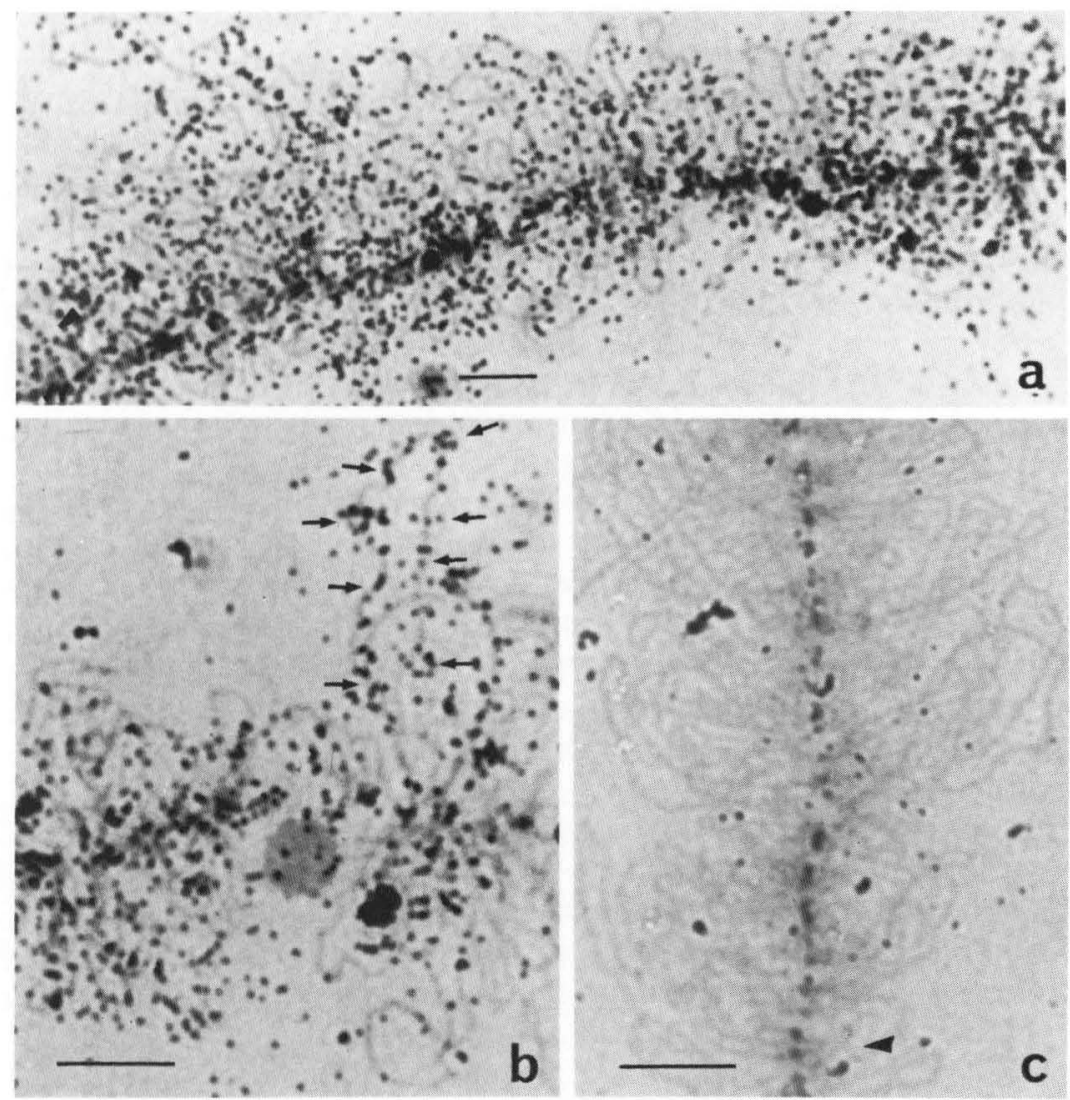

Fig. 7. Autoradiographs showing in situ hybridization of ${ }^{125}$ I-labelled complementary repeat RNA sequences with RNA transcripts of Triturus lampbrush chromosomes. Double-stranded RNA was prepared from oocyte hnRNA as described for Figure 5, labelled by iodination and incubated with lampbrush chromosome preparations under conditions favouring RNA:RNA hybridization. a Reaction of denatured dsRNA with untreated chromosomes showing silver grains over many loops. b As (a) but showing multiple sites of labelling along individual loops (arrows). $\mathbf{c}$ Reaction of denatured dsRNA with a chromosome preparation that has been pretreated with ribonuclease. The autoradiographic exposure time was 14 days. The bars represent $10 \mu \mathrm{m}$

labelled dsRNA is denatured and incubated with lampbrush chromosome preparations under conditions favouring RNA-RNA duplex formation, subsequent autoradiography reveals that the radioactive RNA sequences are specifically bound at multiple sites on many of the lampbrush loops (Fig. 7a and b). In chromosome preparations which are treated with ribonuclease prior to hybridization, the level of bound radioactivity is much reduced (Fig. $7 \mathrm{c}$ ). Furthermore non-denatured dsRNA does not react to any substantial extent with the lampbrush loops (not shown). These results indicate that hnRNA complementary repeat sequences can hybridize with repeats in nascent RNA and that such repeats are distributed widely throughout 
the nascent transcripts of lampbrush chromosomes. This latter technique has an added advantage over hybridization to DNA on Southern blots, for in the non-denatured chromosome preparation hairpin structures in the nascent RNA are not free to bind the probe sequences. Consequently the grains that are seen in the autoradiographs are due to the location of primarily those sequences that are capable of forming interstrand duplex structures after release of the transcripts from the chromatin.

\section{Discussion}

There is a general interspersion of short repetitive sequences among the single-copy regions of the genomes of eukaryotic organisms (for references see Davidson and Britten, 1979). This type of organization has been particularly well described with respect to the sea urchin genome. In sea urchin eggs, for example, families of repetitive sequences are transcribed into hnRNA, the repetitive elements being found covalently linked to single-copy sequences, particularly in the maternal poly $(\mathrm{A})^{+}$mRNA (Constantini et al., 1980). Furthermore, both complements of each repeat sequence are found to be represented in the hnRNA and mRNA populations, presumably due to transcription in both orientations of repeats of the same family which are located in different transcriptional units.

In the work reported here the complementary repeat sequences found in amphibian oocyte hnRNA are described. In order to help decide the functional significance of these sequences, their occurrence has been examined in the oocytes of amphibia with a wide range of genome sizes. Although all of the organisms examined contain complementary repeats in their hnRNA, there is no constancy in the frequency of their occurrence, nor is there any clear-cut relationship with $\mathrm{C}$-value. For instance, why should the percentage of hnRNA sequence capable of rapidly forming interstrand duplex structures be so much higher for Triturus and Necturus than for Amphiuma? One of several possible explanations is that differences exist in the steady-state frequency of repeats due to their differing stability or to the efficiency of their transfer to the cytoplasm. There is, however, some relationship with $\mathrm{C}$-value when other parameters, such as the average length of individual duplexed structures, the total complexity of repeat sequences in hnRNA and the degree of repetitiveness of each sequence in the genome, are considered. All show some increasing trend with $\mathrm{C}$-value and taken together would suggest that there are some regular features in the production of repeat sequence transcripts.

In Triturus oocyte hnRNA, which was the type most extensively studied, the majority of duplexed RNA lengths are in the range of 600-1,200 bp. This can be compared with Xenopus oocyte hnRNA which has duplex lengths of about 200-300 bp, making them similar in size to the analogous structures described for HeLa cell hnRNA (Fedoroff et al., 1977) and sea urchin egg mRNA (Constantini et al., 1980). In contrast, the hnRNA from Necturus oocytes contains duplexed regions most of which are in the range of $1,200-7,600 \mathrm{bp}$. There is evidence to support the notion that there is 
an increase in the sequence complexity of hnRNA transcribed in the oocytes of higher C-value amphibia (Scheer and Sommerville, 1982). The increase in the sequence complexity of complementary repeats with $\mathrm{C}$-value reported here can, to some extent, be accounted for by the increase in the length of individual repeat sequences, rather than by a greatly increased number of different kinds of repeat. It is interesting to note that, in all of the types of amphibian oocyte hnRNA examined, there are some duplex lengths of 200-300 bp, while longer duplex units do not form a continuous distribution of lengths (Fig. 3). One possible explanation is that the longer repeats have evolved by tandem duplication of basic repeat units of about 200-300 bp to produce discrete classes of multiple length.

In so far as the structural organization of the genome is a record of its evolutionary history, what can be concluded about the occurrence of complementary repeat sequences in the genomes of high C-value amphibia? The generally accepted mechanism of genome expansion is through localized duplication of genetic elements. (The repeat sequences thus formed may either remain in tandem association or be dispersed throughout the genome). One consequence of duplication events is that few truly single-copy sequences are found in the genome of a high C-value organism such as Triturus, rather there are repeat families of sequences which have diverged to various extents (Sommerville and Malcolm, 1976). This concept has gained acceptance also with respect to lower $\mathrm{C}$-value organisms with the discovery of pseudogenes, for instance between the tandemly organized 5S RNA genes of Xenopus (Jacq et al., 1977) and in mammalian globin gene clusters (Leder et al., 1980). Although certain categories of repeat sequence in Triturus tend to remain together on individual chromosomal loops, as is the case with the conserved and tandemly arranged histone gene blocks (Stephenson et al., 1981), the complementary repeats studied in this report are in toto, dispersed throughout the genome. Nevertheless, quantitative considerations suggest that the individual families of these repeat sequences are situated preferentially in the transcribed regions of the genome where their location in different transcriptional units allows them to interact through intermolecular hnRNA association. Although the observed stability of RNA duplex structures indicates that the repeat sequences in the different hnRNA molecules are conserved, the lack in homology of repeat sequences between different genera of amphibia indicates that the repeat families either have had independent origins in different taxa or else have diverged in concert (Arnheim et al., 1981).

Two widely different views on the possible function of repeat sequences have been considered previously: that the repeats are essential for gene regulation (Davidson and Britten, 1979), or that they represent some type of "selfish" and not necessarily functional DNA (Doolittle and Sapienza, 1980; Orgel and Crick, 1980). An important factor with respect to function might be the specific location of the repeat sequences with respect to the coding sequences. In amphibian cells, repeats are located at sites flanking, and intervening in, transcribed genes. For instance, the histone gene blocks in the newt Notopthalmus are interspersed with "satellite" sequences which 
consist of 222 bp tandem repeats (Stephenson et al., 1981). In different transcriptional units, transcription takes place on one or other strand, resulting in transcripts containing coding and satellite sequences of both polarities (Diaz et al., 1981). It appears that transcription is initiated at histone gene promotors, fails to terminate at the end of the gene block and continues to variable extent into the satellite region. More typical intermediately repetitive sequences are found in both flanking regions and introns of vitellogenin genes in Xenopus (Ryffel et al., 1981). There are at least six such sequences which are located within the vitellogenin genes and which are found also to occur a few hundred to a few thousand times in the genome. Since these repeats are also transcribed in non-vitellogenic liver cells, it seems likely that they are present in transcriptional units other than those induced by oestrogen. Therefore, even in these two specific situations, a regulatory function for the repeats is not immediately obvious.

However, complementary repeat sequences that exist in hnRNA and mRNA need not represent merely the remains of transcriptional or processing signals. In oocytes and eggs, a possible function is that the transcribed repeats influence the distribution or utilization of sequences for translation during oogenesis (Davidson and Britten, 1979; Thomas et al., 1981). One question that may be important is whether or not complementary repeat sequences interact extensively in vivo. If they do, then it is significant that the dsRNA regions thus formed do not bind those proteins which have a specific affinity for hnRNA and mRNA in general (P.M. Kloetzel and J. Sommerville, unpublished) a property that has been described for hnRNA from other sources (Martin et al., 1978; Calvert and Pederson, 1979).

Acknowledgements. This work was supported by research grants from the Science Research Council of Great Britain (GR/A/97219) and the Deutsche Forschungsgemeinschaft and formed a contribution to the EMBO 3rd Arolla Workshop, 1980. We thank Dr. Hanswalter Zentgraf for his advice on the preparation of RNA for electron microscopy.

\section{References}

Arnheim, N., Krystal, M., Schmickel, R., Wilson, G., Ryder, O., Zimmer, E.: Molecular evidence for genetic exchange among ribosomal genes on non-homologous chromosomes in man and apes. Proc. Natl. Acad. Sci. (Wash.) 77, 7323-7327 (1981)

Britten, R.J., Graham, D.E., Neufeld, B.R.: Analysis of repeating DNA sequences by reassociation. Methods Enzymol. 29E, $363-406$ (1974)

Callan, H.G., Old, R.W.: In situ hybridization to lampbrush chromosomes: a potential source of error exposed. J. Cell Sci. 41, 115-123 (1980)

Calvert, J.P., Pederson, T.: Photochemical cross-linking of secondary structure in HeLa cell heterogeneous nuclear RNA in situ. Nucleic Acids Res. 6, 1993-2001 (1979)

Constantini, F.D., Britten, R.J., Davidson, E.H.: Message sequences and short repetitive sequences are interspersed in sea urchin egg poly (A) ${ }^{+}$RNAs. Nature (Lond.) 287, 111-117 (1980)

Darnell, J.E.: Transcription units for mRNA production in eukaryotic cells and their DNA viruses. Prog. Nucleic Acid Res. Molec. Biol. 22, 327-353 (1979)

Davidson, E.H.: Gene activity in early development. New York: Academic Press 1976

Davidson, E.H., Britten, R.J.: Regulation of gene expression: possible role of repetitive sequences. Science 204, 1052-1059 (1979)

Davidson, E.H., Hough, B.R.: Genetic information in oocyte RNA. J. molec. Biol. 56, 491-506 (1971) 
Diaz, M.O., Barsacchi-Pilone, G., Mahon, K.A., Gall, J.G.: Transcripts from both strands of a satellite DNA occur on lampbrush chromosome loops of the newt Notophthalmus. Cell 24, 649-659 (1981)

Doolittle, W.F., Sapienza, C.: Selfish genes, the phenotype paradigm and genome evolution. Nature (Lond.) 284, 601-603 (1980)

Fedoroff, N., Wellauer, P.K., Wall, R.: Intermolecular duplexes in heterogeneous nuclear RNA from HeLa cells. Cell 10, 597-610 (1977)

Glison, V., Crkvenjakov, R., Byus, C.: Ribonucleic acid isolated by cesium chloride centrifugation. Biochemistry 13, 2633-2637 (1976)

Gurdon, J.B.: The control of gene expression in animal development. Oxford: Clarendon Press 1974

Jacq, C., Miller, J.R., Brownlee, G.G. : A pseudogene structure in 5S DNA of Xenopus laevis. Cell 12, 109-120 (1977)

Jelinek, W.R., Toomey, T.P., Leinwand, L., Duncan, C.H., Biro, P.A., Choudary, P.V., Weissman, S.M., Rubin, C.M., Houck, C.M., Deininger, P.L., Schmid, C.W.: Ubiquitous interspersed repeated sequences in mammalian genomes. Proc. Natl. Acad. Sci. (Wash.) 77, 1398-1402 (1980)

Leder, P., Hansen, J.N., Konkel, D., Leder, A., Nishioka, Y., Talkington, C. Mouse globin system: a functional and evolutionary analysis. Science 209, 1336-1342 (1980)

Malcolm, D.B., Sommerville, J.: The structure of nuclear ribonucleoprotein of amphibian oocytes. J. Cell Sci. 24, 143-165 (1977)

Martin, T.E., Billings, P.B., Pullman, J.M., Stevens, B.J., Kinniburgh, A.J.: Substructure of nuclear ribonucleoprotein complexes. Cold Spring Harbor Symp. Quant. Biol. 42, 899-909 (1978)

Old, R.W., Callan, H.G., Gross, K.W.: Localization of histone gene transcripts in newt lampbrush chromosomes by in situ hybridization. J. Cell Sci. 27, 57-97 (1977)

Orgel, L.E., Crick, F.H.C.: Selfish DNA: the ultimate parasite. Nature (Lond.) 291, 429-431 (1980)

Ryffel, G.V., Muellener, D.B., Wyler, T., Wahli, W., Weber, R.: Transcription of single copy vitellogenin gene of Xenopus laevis involves expression of middle repetitive DNA. Nature (Lond.) 291, 429-431 (1981)

Ryskov, A.P., Farashyan, V.N., Georgiev, G.P.: Ribonuclease-stable base sequences specific exclusively for giant dRNA. Biochim. Biophys. Acta 262, 568-572 (1972)

Scheer, U., Sommerville, J.: Sizes of chromosome loops and hnRNA molecules in oocytes of amphibia of different genome sizes. Exp. Cell Res. 139, 410-416 (1982)

Sommerville, J.: Transcription during amphibian oogenesis. In Maternal effects in development. (D.R. Newth and M. Balls, eds.) pp. 47-63. Cambridge University Press 1979

Sommerville, J., Malcolm, D.B.: Transcription of genetic information in amphibian oocytes. Chromosoma (Berl.) 55, 183-208 (1976)

Sommerville, J., Scheer, U.: Structural organization of nascent transcripts and hnRNA molecules in amphibian oocytes. Mol. Biol. Rep. 7, 53-56 (1981)

Southern, E.: Detection of specific sequences among DNA fragments separated by gel electrophoresis. J. Molec. Biol. 98, 503-517 (1975)

Stephenson, E.C., Erba, H.P., Gall, J.G.: Histone clusters of the newt Notophthalmus are separated by long tracts of satellite DNA. Cell, 24, 639-647 (1981)

Thomas, T.L., Posakony, J.W., Anderson, D.M., Britten, R.J., Davidson, E.H.: Molecular structure of maternal RNA. Chromosoma (Berl.) 84, 319-335 (1981)

Varley, J.M., Macgregor, H.C., Nardi, I., Andrews, C., Erba, H.P.: Cytological evidence of transcription of highly repeated DNA sequences during the lampbrush stage in Triturus cristatus carnifex. Chromosoma 80, 289-307 (1980)

Wellauer, P.K., Dawid, I.B.: Secondary structure maps of ribosomal RNA and DNA. J. molec. Biol. 89, 379-395 (1974) 